\title{
EMPIRICAL EVIDENCE OF ASSET PRICING BASED ON SINGLE INDEX MODEL, FAMA, AND FRENCH THREE AND FIVE-FACTOR MODELS IN INDONESIA STOCK EXCHANGE
}

\author{
Ani Silvia ${ }^{1}$, Chikita Tiara Griska ${ }^{2}$ \\ Universitas Muhammadiyah Prof. DR. Hamka, Jakarta ${ }^{1}$ \\ Universitas Tridinanti Palembang, Palembang ${ }^{2}$ \\ ${ }^{I}$ Corresponding author: ani.silvia@uhamka.ac.id (iD https://orcid.org/0000-0001-6831-0011
}

\begin{abstract}
INFORMASI ARTIKEL ABSTRAK
Article history:

Dikirim l: 12 Maret 2021

Revisi pertama: $20 / 04 / 2021$

Diterima: 05/06/2021

Tersedia online: $21 / 06 / 2021$

Uji empiris ini bertujuan untuk mengestimasi parameter beta dari premi risiko dan faktor risiko lainnya serta membandingkan kinerja model indeks tunggal, Fama dan French model tiga dan lima faktor. Penelitian ini menggunakan sampel berupa perusahaan subsektor property dan real estate dengan data yang dikumpulkan dari datastream Thomson Reuters dari Januari 2014 sampai dengan Desember 2018. Sejalan dengan penelitian sebelumnya, penelitian ini menemukan bahwa asset pricing menggunakan model Fama dan French dengan lima faktor dapat menjelaskan imbal hasil saham dengan lebih baik daripada dua model lainnya. Subsektor properti dan real estate terlihat memberikan abnormal return yang positif dan signifikan secara statistik, yang mengindikasikan bahwa asset pricing dengan ketiga model tersebut tidak relevan untuk diterapkan di Indonesia. Hasil ini menunjukkan bahwa pasar saham di Indonesia masih kurang efisien.
\end{abstract}

Kata Kunci: asset pricing, model indeks tunggal, model Fama and Frenchtiga dan lima faktor, risiko, imbal hasil

\footnotetext{
ABSTRACT

This empirical test aims to estimate the beta parameters of the risk premium and other risk factors and compare the performance of the singleindex model, Fama and Frech three and five-factor models. The sample used as the study object is companies in the property and real estate subsector with data collected from datastream Thomson Reuters from January 2014 to December 2018. The results are consistent with the previous studies that asset pricing using the Fama and French five-factor model can better explain stock returns than the other two models. The property and real estate subsector seems to provide a positive and statistically significant abnormal return, indicating that asset pricing with the three models is irrelevant to Indonesia. These results suggest that the stock market in Indonesia is still inefficient.
}

Keywords: $\quad$ asset pricing, single index model, Fama and French three and fivefactor model, risk, return

C2018 FEB UNRAM. All rights reserved

DOI: $10.29303 /$ akurasi.v4i1.82

Open access under Creative Commons Attribution-ShareAlike 4.0 International License.

(CC-BY-SA) 


\section{Introduction}

Investments in property and real estate are long-term investments and will grow in line with economic growth and are believed to be the most promising investments. In making investment decisions, investors are always faced with returns and risks. The notion of high-risk will earn high returns, and the low-risk will provide a low return, which has become a general concept understood by investors. In investing in the capital market, especially buying stock securities, investors will consider the stock returns they will get. If a stock provides high returns, it will be more desirable. For this reason, investors pay attention to how to predict the return of their portfolio. Several factors affect stock portfolio returns that have been proposed in several asset pricing models. Each asset pricing model proposes different factors. This difference raises the question, which of the models offered is the best model. Therefore, the proposed asset pricing models need to be compared, which asset pricing models have better explanatory power for average stock returns.

Fama and French offer an asset pricing model with three factors: market beta, size, and book-to-market equity. Their model can explain the average stock return compared with one factor (Fama \& French, 1992). Previously, the asset pricing model was initiated by Sharpe (1964), Lintner (1965), and Black (1976). They state that the average stock return is positively associated with market beta. Thus, the developed model implies a trade-off between risk and return and is often known as the Capital Asset Pricing Model (CAPM). Fama and French three-factor model is still controversial because it is considered imperfect, and other important factors still need to be included in the model. Research conducted by Titman et al. (2004) shows that low average returns follow high investment in the context of stock returns in the US for the period July 1973 - June 1996. They used capital expenditure to measure the company's capital investment and explained agency cost related to the negative relationship between investment and stock return. In addition, Watanbe et al. (2013) examined the relationship between investment as measured by asset growth and stock returns in developed and emerging markets for July 1982 - June 2006. Their findings support the study of Titman et al. (2004), emphasizing optimal investment explanation. Another, Novy-Marx (2013), in their research using US data and a developed market outside the US for July 1963 - December 2010, shows that high profitability is associated with high future returns. Companies that have profitability can generate a higher average return than companies that are not. Fama \& French (2015) then examined the significance of these two factors, namely investment and profitability factors to be considered in the model.

Fama \& French (2017) verified the five-factor model in the global market: in North America, Europe, and the Asia Pacific period July 1990 to December 2015. Their findings indicate that the five-factor model can explain the average returns pattern superiorly to the three-factor model. The average stock return increases with the book-to-market ratio and profitability but is negatively related to the investment factor. Although there are still redundancy issues, the eminent of the five-factor model has also been proven again in the capital markets of Australia (Chiah et al., 2016), China (Huang, 2019; Lin, 2017), Eastern Europe and Latin America (Foye, 2018), and in South Africa (Cox \& Britten, 2019). In addition, Sutrisno \& Ekaputra (2016) tested this model on the Indonesian stock market. 
This study indicates that the five-factor model explains more about portfolio excess return than the three-factor model. However, profitability and also investment elements have a poor effect on excess return. According to them, this model is invalid due to abnormal differences and market efficiency in Indonesia and the US market. However, they only compared the two models and left a single index model in their analysis.

This article aims to reexamine how the three different models perform using different samples which are homogeneous in one industrial sector, namely the property and real estate sector. This study will compare the single index model, Fama and French threefactor and five-factor models. Which of these three factors are better in elucidating the average return of the stock in Indonesia? Indonesia is one of the countries in emerging markets with interesting characteristics. Trading volume in Indonesia is referred to as thin trading because of the unsynchronized trade. Many companies are listed on the exchange but not entirely traded. This characteristic of trading volume makes stock portfolios formed in the Indonesian capital market very limited, especially in Fama and French three-factor and five-factor models of asset pricing. The Three-factor and five-factor models of Fama and French require the formation of multiple portfolios based on the proposed additional risk factors. This limitation allows the asset pricing model offered by Fama and French to produce different findings when applied in Indonesia. This study focuses on using stocks in the property and real estate subsector because it is one of the most attractive sectors for investors and because property prices always increase all the time. This study contributes in the form of a theory that explains the best model of the three asset pricing models that have been previously mentioned. Therefore, it adds literature on the topic of asset pricing in Indonesia. This study is also useful for long-term investors to consider several important factors when investing in the Indonesian capital market, especially on stocks in the property and real estate sectors.

\section{Literature Review}

The modern portfolio theory introduced by Harry Markowitz (1959) has successfully defined and measured stock portfolio risk. Then afterwards, many researchers try to find an association between risk and stock returns. Separately, Sharpe (1964), Lintner (1965), and Black (1976) proposed a theoretical model for asset pricing, which is currently known as the Capital Asset Pricing Model (CAPM). In this initial asset pricing model, stock return is only influenced by one factor; a systemic risk denoted as beta. Beta represents a market risk that is valued in assessing the return of an asset. Under CAPM, there is a trade-off between risk and return where assets with high risk will also provide high returns. CAPM is an equilibrium model where there is an assumption that the supply and demand sides of an asset are the same so that the price that occurs is the equilibrium price. CAPM has become the benchmark of existing asset pricing models and has been widely used to calculate asset prices and a reference model for calculating the cost of capital by many empirical studies (Shih et al., 2014). As predicted by Sharpe (1964), Lintner (1965), and Black (1976), there is a positive link between market beta and average stock returns.

Many assumptions are put forward in the CAPM. These assumptions are intended to simplify problems amidst the complexity of asset price formation. Some of the 
assumptions that become the traditional CAPM approach are that all agents, in this case, investors have the same beliefs about future returns (homogeneous expectations) and are risk-averse. There are risk-free assets where investors can borrow and lend. The optimal portfolio structure is the same for all investors. Other assumptions are that there are no transaction costs, no taxes, no regulations, and restrictions on short selling. As an alternative to simple asset pricing and also providing an alternative to calculating portfolio diversification by Harry Markowitz (1959), Sharpe (1963) proposed a single index model for the first time. The stock index is a valid proxy for macroeconomic factors (Bodie, Kane, \& Marcus, 2014). The single index model utilizes the stock index to estimate the systematic risk that represents market beta. Sharpe (1963) proposed the basic idea of using the stock index as the only risk factor in the model based on the observation that the stock price index will significantly influence the stock price. If the stock price index rises, most of the stock prices will go up as well. Vice versa, if the stock price index falls, most of the stock prices will also decrease. Because using the stock index as the only risk factor in the model, the equation for the model is the same as the single-factor CAPM model.

The assumptions in the CAPM that are too strict have made many researchers try to build a more general asset pricing model by loosening existing assumptions. For example, Shih et al. (2014) have documented at least two types of CAPM, namely the static CAPM and the dynamic CAPM. The beta in static CAPM is constant over time, while in dynamic CAPM, there is multi-beta because the investment opportunities are stochastic with multiperiod characteristics. According to the consensus, the single-factor static CAPM has not explained the average stock return by cross-section. For this reason, in their paper, Fama \& French (1992) tries to review what factors can explain the average stock return apart from market beta. They document several other factors that a number of researchers have previously examined besides market beta, such as the size effect, the firm's book value of common equity ratio, leverage, and the earnings-price ratios. From several variables reviewed, Fama \& French (1992) found that variable size (market capitalization) and variable value (book-to-market equity) provide a modest and robust explanation for the average stock return for the period 1963-1990 in the US. For this reason, they propose an asset pricing three-factor model, which includes three factors, namely the market beta, the size, and the value effect.

In the Fama \& French three-factor model, there is a different relationship between the average stock return and the three proposed risk factors. Supporting the statement previously described, market beta and average stock returns have a positive relationship supporting the trade-off concept. The size effect and average stock return have a negative relationship, which supports the results of a study conducted by Banz (1981) that states that smaller stocks have higher risk-adjusted returns than bigger stocks on NYSE common stocks. According to Fama \& French (1992), there is a strong positive link between average return and book-to-market equity. Harvey et al. (2016) confirmed the strength of this relationship when conducting multiple testing frameworks and providing cutoff tstatistic values for all proposed risk factors. Book-to-market equity provides a t-statistic value that is much higher than the cutoff value. The high book-to-market ratio accompanied by negative book equity signals that the company has poor profit prospects. In addition, a high book-to-market ratio also indicates high market leverage of the 
company compared to its book leverage, so that the market perceives the company as having bad prospects and discounts the company's stock price. Thus, the book-to-market effect is more superior to the size effect, and the coalition of the two captures the role of leverage and the earnings-price ratios in explaining average stock returns.

Fama \& French (2015) consider two risk factors, namely profitability and investment, to be included in their asset pricing model after re-test the significance of these two factors. According to Novy-Marx (2013), variable profitability gauged by gross profits-to-assets experiences the same explanatory power as book-to-market equity in elucidating the average stock return by cross-section. There is a positive link between profitability and average stock returns. Profitable companies generate a higher average stock return when compared to companies that are not profitable. Novy-Marx (2013) explains that investors can use two similar strategies based on value and profitability. The value strategy recommends investors buy cheap assets (high book-to-market ratio) by selling expensive assets. Buying value stocks and selling growth stocks is an effective way to exploit stock miss valuation. Meanwhile, the profitability strategy suggests that investors buy productive assets by selling unproductive assets. A profitable company, in this case, is a productive asset.

According to theory, investment spending by companies provides both positive and negative signals. A large investment expenditure indicates that the company has better investment opportunities. However, investment can also negatively signal that the company is led by managers who tend to overinvest. Titman et al. (2004) discovered a negative and significant link between investment and stock returns. Companies that increase their investment capital tend to have low returns in the next five years. According to Titman et al. (2004), this negative relationship is caused by a lack of appreciation from investors in companies that overinvest related to manager intentions. Another possibility could be due to the supply side, where companies tend to invest more when the cost of capital is low. This last opinion is supported by Watanbe et al. (2013) stated that the company would try to achieve the optimal level of investment by looking for a lower discount rate to maximize the present value of the company's free cash flow.

Fama \& French (2018) tried to compare the CAPM model with a single factor, Fama \& French three factors, and five factors using the maximum squared Sharpe ratio. The max Sharpe ratio is used to see whether each factor explains the model's average return. The higher the value of the max squared Sharpe ratio indicates that the factor added makes a marginal contribution in the model. They found that the five-factor model gave the max squared Sharpe ratio higher than the CAPM and three-factor models.

\section{Method}

This study used a sample of 42 companies from 61 companies in the property and real estate subsector from January 2014 to December 2018 by using monthly data frequency and providing 60 observation data in time series. The sample was determined based on purposive sampling because several companies had to be excluded due to incomplete data available. Some of the data collected are index prices, share prices, number of outstanding shares, 90-day SBI interest rates, book value per share, operating profit, and total company assets obtained through datastream from Thomson Reuters. The 
index prices and stock prices are used to find the return index and return of each company. This study will compare the portfolio stock return measured using three models: the single index model, Fama and French three-factor and five-factor models with the formula in equations (1,2 and 3$)$, respectively.

$$
\begin{array}{r}
R_{i t}=\alpha_{i}+\beta_{i} R_{m t}+\varepsilon_{i t} \\
R_{i t}=\alpha_{i}+\beta_{i} R_{m t}+\gamma_{i} S M B_{t}+\delta_{i} H M L_{t}+\varepsilon_{i t} \\
R_{i}=\alpha_{i}+\beta_{i} R_{m t}+\gamma_{i} S M B_{t}+\delta_{i} H M L_{t}+\zeta_{i} R M W_{t}+\eta_{i} C M A_{t}+\varepsilon_{i t}
\end{array}
$$

$\mathrm{R}_{\mathrm{it}}$ is a portfolio return that has been averaged on a weighted basis based on its size subtracted the risk-free rate, namely the 90 -day $\mathrm{SBI}$ interest rate. $\mathrm{R}_{\mathrm{m}}$ is the market risk premium; namely, the market return subtracted the risk-free rate, while alpha is the excess or abnormal return. Beta is the risk premium slope, which indicates the sensitivity of the portfolio return to the return index, which is a proxy for the market. Gamma, delta, zeta, and eta are each slope for size, value, profitability, and investment factors, successively. SMB or Small Minus Big is the difference from the weighted average stock return between companies with a small size (market capitalization) and a large size. Market capitalization is interpreted as the stock price multiplied by the number of shares outstanding.

Meanwhile, HML or High Minus Low is different from the weighted average stock return between companies with high and low book-to-market ratios. The book-to-market ratio is calculated as the ratio of the company's book equity to market equity. Finally, RMW or Robust Minus Weak differs from the weighted average stock returns between companies with high profitability and low profitability. Profitability is measured using operating income, which is income obtained from the company's operating activities. Operating income is often referred to as net operating profit after tax at the end of fiscal year t-1. Finally, CMA or Conservative Minus Aggressive is the distinction from the weighted average stock return between those with low asset growth and high asset growth as a proxy for investment factors. Asset growth is measured using the following formula:

$$
A G=\frac{T A_{t-1}-T A_{t}}{T A_{t-1}}
$$

Where AG is Asset Growth, $\mathrm{TA}_{\mathrm{t}-1}$ is total assets in year $\mathrm{t}-1$, and $\mathrm{TA}_{\mathrm{t}}$ is total assets in year $\mathrm{t}$.

To get the final data in the form of 60-time series data for multiple linear regression, data from 42 companies were analyzed cross-section by forming a portfolio each month. Portfolio construction follows the rules of Fama \& French (2015) with a 2x2 scheme where companies are grouped based on the median. The use of the $2 \times 2$ scheme, according to Fama \& French (2015), is preferred because the $2 \times 2$ scheme is better diversified by using all existing stocks than the $2 \times 3$ scheme and the $2 \times 2 \times 2 \times 2$ scheme. Before forming a portfolio, the company's stock returns were split into two groups based on the median size, book-to-market ratio, operating income, and asset growth. Stock returns with the largest size, 50\%, will be grouped into company stock returns with the big size. 
On the other hand, those below the median will be grouped into small-sized stock returns. And so on for the distribution of stock returns based on the book to market ratio, operating income, and asset growth. After being divided into Small-Big (SB), High-Low (HL), Robust-Weak (RW), and Conservative-Aggressive (CA) categories, 12 portfolios were created consisting of a combination of sizes with other characteristics. For example, Small-High (SH) is a small company's stock return but has a high book-to-market ratio. Thus, twelve portfolios have been formed, which the composition is changed every year based on size and book-to-market ratio, size and operating income, and size and asset growth. Specifically for size, portfolio formation is carried out every June of the year $t$ because it considers the number of companies that have not released audited financial reports at the end of the year. Thus, it is estimated that the market reaction will require a lag time of 6 months later. For book-to-market, operating income, and asset growth, the portfolio's formation is carried out at the end of each year in period t-1.

After obtaining the twelve portfolios mentioned earlier, the SMBt value is calculated: the average number of stock returns from all portfolios with small size minus the number of stock returns from big-sized portfolios. All portfolios are shaped based on the size of twelve portfolios, which are a combination of small size and high book-tomarket ratio (SH), small size and low book-to-market ratio (SL), small size and high profitability (SR), small size and low profitability (SW), small size and low asset growth (SC), small size and high asset growth (SA), and so on for the combination of big size stock. Formula 5 is used to calculate time series SMBt.

$$
\begin{array}{r}
S M B_{t}=\frac{(S H+S L+S R+S W+S C+S A)-(B H+B L+B R+B W+B C+B A)}{6} \\
H M L_{t}=\frac{(S H+B H)-(S L+B L)}{2} \\
R M W_{t}=\frac{(S R+B R)-(S W+B W)}{2} \\
C M A_{t}=\frac{(S C+B C)-(S A+B A)}{2}
\end{array}
$$

The HMLt value is obtained from the average number of stock returns from all portfolios with a high book-to-market ratio minus the total stock returns of all portfolios with a low book-to-market ratio. Portfolios for value, profitability, and investment are only combined with stock size. HMLt, RMWt, and CMAt were calculated using formulas 6, 7 , and 8 , respectively. The next step is to perform linear regression by entering the value of each factor obtained.

\section{Result and Discussion}

A summary of the results of the descriptive statistics of the variables used can be seen in Table 1 below. Table 1 shows the average return on the property and real estate subsector portfolio during the study period, which is $2.42 \%$ per month or around $29.04 \%$ a year. This value is quite large, so that investors can consider this subsector to be included in their investment portfolio. The average risk premium from the market is $-5.74 \%$ per month. The average risk premium of the size factor is positive, $0.93 \%$ per month. The 
average risk premium of the value factor HML, RMW, and CMA is $-3.23 \%,-0.98 \%$, and $0.92 \%$ per month, respectively.

Table 1. Descriptive statistics

\begin{tabular}{lrrrrrr}
\hline & Return & $\begin{array}{c}\text { Risk } \\
\text { Premium }\end{array}$ & SMB & HML & RMW & CMA \\
\hline Mean & 0.0242 & -0.0574 & 0.0093 & -0.0323 & -0.0098 & -0.0092 \\
Median & 0.0118 & -0.0556 & 0.0125 & -0.0157 & -0.0135 & -0.0024 \\
Maximum & 0.1721 & 0.0147 & 0.1330 & 0.0874 & 0.1532 & 0.1061 \\
& - & & & & & \\
Minimum & 0.0775 & -0.1445 & -0.1111 & -0.2503 & -0.2536 & -0.1458 \\
Std. Dev. & 0.0578 & 0.0324 & 0.0569 & 0.0813 & 0.0674 & 0.0502 \\
N & 60 & 60 & 60 & 60 & 60 & 60 \\
Number of Firms & 42 & 42 & 42 & 42 & 42 & 42 \\
\hline
\end{tabular}

Table 2. Correlation between variables

\begin{tabular}{|c|c|c|c|c|c|c|}
\hline $\begin{array}{l}\text { Correlation } \\
\text { (t-Statistic) } \\
\text { Return } \\
\end{array}$ & $\begin{array}{l}\text { Return } \\
1 \\
\end{array}$ & Market & SMB & HML & RMW & CMA \\
\hline Return & ------ & & & & & \\
\hline \multirow[t]{2}{*}{ Market } & $0.63 * * *$ & 1 & & & & \\
\hline & (6.21) & ----- & & & & \\
\hline \multirow[t]{2}{*}{ SMB } & $-0.25^{*}$ & $-0.24 *$ & 1 & & & \\
\hline & $(-2.00)$ & $(-1.85)$ & ----- & & & \\
\hline \multirow[t]{2}{*}{ HML } & -0.21 & -0.13 & $-0.54 * * *$ & 1 & & \\
\hline & $(-1.66)$ & $(-0.97)$ & $(-4.87)$ & ----- & & \\
\hline \multirow[t]{2}{*}{ RMW } & $0.43^{* * *}$ & $0.36^{* * *}$ & -0.16 & 0.21 & 1 & \\
\hline & (3.66) & (2.96) & $(-1.26)$ & (1.63) & ----- & \\
\hline \multirow[t]{2}{*}{ CMA } & $-0.36 * * *$ & $-0.40 * * *$ & 0.15 & 0.18 & -0.39 & 1 \\
\hline & $(-2.92)$ & $(-3.37)$ & (1.13) & $(1.40)$ & $(-3.20)$ & ----- \\
\hline
\end{tabular}

*** Significant at $1 \%$ level, ** Significant at $5 \%$ level, $*$ Significant at $10 \%$ level

Table 2 denotes the correlation value between the variables used. Portfolio return has a positive and significant relationship with market risk premium (0.63) and profitability factors $(0.43)$ but negatively correlates with the size $(-0.25)$ and investment factors (-0.36). Trade-off risk and return are seen with a significant positive correlation between market risk premium and portfolio returns, supporting the predictions of Sharpe (1964), Lintner (1965), and Black (1976). The correlation between return and risk premium value HML is negative but not significant. Interestingly, supporting the study's results by Fama \& French (1992), the correlation between the size and value of HML is negative and significant. This negative correlation indicates that small companies are likely to have low prospects to have low stock prices and have a high book-to-market equity ratio. The regression results from the single index model, Fama and French three-factor and five-factor model are presented in Table 3. The t-statistic and standard error values have been adjusted to avoid heteroscedasticity and autocorrelation problems using Newey and West. The three models' alpha value, which is positive and significant at the $1 \%$ level, indicates that the property and real estate subsector's portfolio return provides a positive abnormal return. Thus, it suggests that the stock market is still inefficient or that the model specifications used are still insufficient to explain the average stock return. This finding aligns with the outcomes of a study conducted by Sutrisno \& Ekaputra (2016). 
The three models' beta value of the market risk premium is also positive and significant at the $1 \%$ level supporting the trade-off between risk and return. Thus, the market risk premium is an important variable that can explain portfolio returns. The beta of the size risk premium has a significant negative value at the level of 5\% (FF three-factor is $-29.9 \%$ with $\mathrm{t}$-statistic -2.38 ) and $1 \%$ (FF five-factor is $-35.4 \%$ with $\mathrm{t}$-statistic -2.83 ). This value means that the size risk premium has a negative and significant impact on the average portfolio return. The negative relationship between the size effect and the average stock return supports the results of research conducted by Banz (1981) and Fama \& French (1992) that smaller stocks have higher risk-adjusted returns than bigger stocks. This finding indicates that stock returns from portfolios with small sizes have a higher risk, so investors need a higher compensation return than stocks with large size.

Table 3. Regression result for the Single Index Model, Fama and French three and five-factor models

\begin{tabular}{lrrr}
\hline \multicolumn{1}{c}{$\begin{array}{c}\text { Independent } \\
\text { Variables }\end{array}$} & Single index model & FF Three-Factors & FF Five-Factors \\
\hline C & $0.088^{* * *}$ & $0.074 * * *$ & $0.062^{* * *}$ \\
Risk Premium & $(5.97)$ & $(5.06)$ & $(4.13)$ \\
& $1.126^{* * *}$ & $0.934 * * *$ & $(3.15)$ \\
SMB & $(5.39)$ & $-0.299 * *$ & $-0.354 * * *$ \\
& & $(-2.38)$ & $(-2.83)$ \\
HML & & $-0.217 * *$ & $-0.309 * * *$ \\
& & $(-2.50)$ & $(-3.86)$ \\
RMW & & & $0.301 * * *$ \\
& & & $(3.45)$ \\
CMA & & & 0.078 \\
Model Fits: & & & $(0.65)$ \\
Adj. R-squared & 0.3890 & 0.4425 & 0.5178 \\
F-statistic & 38.57 & 16.61 & 13.67 \\
Prob. (F-statistic) & 0.0000 & 0.0000 & 0.0000 \\
N & 60 & 60 & 60 \\
Number of Firms & 42 & 42 & 42 \\
\hline$* * *$ Significant at 1\% level, ** Significant at 5\% level & &
\end{tabular}

The value risk premium is significant negative at the 5\% level (FF 3 factor is $21.7 \%$ t-statistic -2.5 ) and $1 \%$ (FF 5 factor is $-30.9 \%$ t-statistic -3.86 ), which means the risk premium of the book-to-market ratio has a negative influence on the average portfolio return. This finding disproves the findings of Fama \& French (1992), where they found a positive and significant link between average returns and book-to-market equity. The negative relationship found in this study indicates that companies with a high book-tomarket ratio have a low average return. This is because companies with high book-tomarket ratios are value stocks and have poor profit prospects. In addition, a high book-tomarket ratio also indicates high market leverage of the company compared to its book leverage, so that the market perceives the company as having bad prospects and discounts the company's stock price. This negative relationship indicates that portfolios with high book-to-market ratios carry more unsatisfactory performance than portfolios with low book-to-market ratios.

Profitability premium, which has a significant positive effect on average returns (30.1\% with a t-statistic of 3.45$)$, indicates that portfolio returns with high profitability 
have better performance than portfolios with low profitability. This finding is in line with the outcomes of a study conducted by Novy-Marx (2013), which states that profitable companies produce a higher average stock return than companies that are not profitable. Meanwhile, the risk premium does not significantly affect the average return $(7.8 \%$ with a $\mathrm{t}$-statistic of 0.65$)$. The investment factor, which does not have explanatory power for average stock returns, does not support the findings of Titman et al. (2004) and Watanbe et al. (2013). For the portfolio case, especially companies in the property and real estate sector, the investment made by the company does not provide a positive signal or a negative signal for investors so that investors do not appreciate or depreciate investment spending.

Overall, the single-index model, Fama and French three factors, and five factors can explain the average portfolio return. All three models have a reasonably high adjusted R-squared value, namely $38.9 \%, 44.25 \%$, and $51.78 \%$, respectively. The probability $\mathrm{F}$ values are significant at the $1 \%$ level. The single index model, which has an adjusted Rsquared value of $38.9 \%$, indicates that the market risk premium can explain the average portfolio return of $38.9 \%$. In contrast, the rest is explained by other risk factors that are not in the model. The increase in the adjusted R-squared value in the Fama and French threefactor and five-factor models indicates that this model can explain the average portfolio returns better than the single-index model. The outcomes of this study are in line with research conducted by Fama \& French (2018) and Sutrisno \& Ekaputra (2016) using the adjusted R-squared value that the five-factor model outperformed the three-factor and single-factor models. However, the five-factor model is the best because it provides the highest adjusted R-squared value relative to the other two models.

\section{Conclusion}

This study compares three asset pricing model performance: the single index model, Fama and French three-factor, and five-factor models, explaining the value of the portfolio returns from the property and real estate subsector. Using a sample of 42 companies from January 2014 to December 2018, the study shows that the three models can explain portfolio returns because of a reasonably high adjusted R-squared value and a significant F-statistic. However, from the three models, the Fama and French five-factor model is the best because it has the highest adjusted R-squared value. The three models provide positive and significant alpha values indicating the abnormal return investors can get if they form a homogeneous portfolio of stocks in the property and real estate subsector. The significant alpha values align with Sutrisno \& Ekaputra's (2016) findings that an abnormal return indicates inefficiency in Indonesia's stock market. However, the significant alpha can also show that the asset pricing models used are insufficient to explain average returns. Maybe there are still other factors that can explain it.

The study reports that the size risk premium is negative, which is conformable with the previous findings of Banz (1981) and Fama \& French (1992). The risk premium of the book-to-market ratio has a negative impact on the average portfolio return, denoting that a portfolio with a high book-to-market ratio has worse performance than a portfolio with a low book-to-market ratio. Profitability premium, which has a significant positive impact on average returns, indicates that portfolio returns with high profitability have better 
performance than portfolio returns with low profitability. Finally, the investment factor does not significantly affect portfolio return.

\section{References}

Banz, R. W. (1981). The relationship between return and market value of common stocks. Journal of Financial Economics, 9(1), 3-18.

Black, S. W. (1976). Rational response to shocks in a dynamic model of capital asset pricing. The American Economic Review, 66(5), 767-779.

Bodie, Z., Kane, A., \& Marcus, A. J. (2014). Investments (10th ed.). New York: McGrawHill Education.

Chiah, M., Chai, D., Zhong, A., \& Li, S. (2016). A Better Model? An empirical investigation of the Fama-French five-factor model in Australia. International Review of Finance, 16(4), 595-638. https://doi.org/10.1111/irfi.12099

Cox, S., \& Britten, J. (2019). The Fama-French five-factor model: evidence from the Johannesburg Stock Exchange. Investment Analysts Journal, 48(3), 240-261. https://doi.org/10.1080/10293523.2019.1647982

Fama, E. F., \& French, K. R. (2015). A five-factor asset pricing model. Journal of Financial Economics, 116, 1-22.

Fama, E. F., \& French, K. R. (2017). International tests of a five-factor asset pricing model. Journal of Financial Economics, 123(3), 441-463. https://doi.org/10.1016/j.jfineco.2016.11.004

Fama, E., \& French, K. (1992). The cross-section of expected stock returns. Journal of Finance, 47(2), 427-465. https://doi.org/10.2307/2329112

Fama, Eugene F., \& French, K. R. (2018). Chosing Factors. Journal of Financial Economics, 128, 234-252.

Foye, J. (2018). A comprehensive test of the Fama-French five-factor model in emerging markets. Emerging Markets Review, 37, 199-222. https://doi.org/10.1016/j.ememar. 2018.09.002

Harvey, C. R., Liu, Y., \& Zhu, H. (2016). ... and the cross-section of expected returns. The Review of Financial Studies, 29(1), 5-68.

Huang, T.-L. (2019). Is the Fama and French five-factor model robust in the Chinese stock market? Asia Pacific Management Review, 24(3), 278--289.

Lin, Q. (2017). Noisy prices and the Fama-French five-factor asset pricing model in China. Emerging Markets Review, 31, 141-163. https://doi.org/10.1016/j.ememar. 2017.04.002 d

Lintner, J. (1965). The Valuation of Risk Assets and the Selection of Risky Investments in Stock Portfolios and Capital Budgets. Review of Economics and Statistics, 47(1), 1337.

Markowitz, H. M. (1959). Portfolio selection: Efficient diversification of investments. John Wiley. 
Novy-Marx, R. (2013). The other side of value: The gross profitability premium. Journal of Financial Economics, 108, 1-28.

Sharpe, W. F. (1964). Capital asset prices: A theory of market equilibrium under conditions of risk. The Journal of Finance, 19(3), 425-442. https://doi.org/10.1111/ j.1540-6261.1964.tb02865.x

Sharpe, William F. (1963). A simplified model for portfolio analysis. Management Science, 9(2), 277-293.

Shih, Y.-C., Chen, S.-S., Lee, C.-F., \& Chen, P.-J. (2014). The evolution of capital asset pricing models. Review of Quantitative Finance and Accounting, 42(3), 415-448.

Sutrisno, B., \& Ekaputra, I. A. (2016). Uji Empiris Model Asset Pricing Lima Faktor Fama-French Di Indonesia. Jurnal Keuangan Dan Perbankan, 20(3), 343-357.

Titman, S., Wei, K. J., \& Xie, F. (2004). Capital Investments and Stock Returns. Journal of Financial and Quantitative Analysis, 39(4), 677-700. https://doi.org/10.1017/ S0022109000003173

Watanbe, A., Yu, Y., Yao, T., \& Yu, T. (2013). The asset growth effect: insights from international equity markets. Journal of Financial Economics, 108, 529-563. 